\title{
Ternatin pretreatment attenuates testicular injury induced by torsion/detorsion in Wistar rats $^{1}$
}

\author{
Pré-tratamento com ternatina atenua a lesão testicular induzida por \\ torção/destorção em ratos Wistar ${ }^{1}$
}

\begin{abstract}
Sergio Botelho Guimarães, Jefferson Menezes Viana Santos" ${ }^{I I}$, Alan Arruda AragãoII, Osamu Sandes Kimura", Edilberto R. Silveira ${ }^{\text {III }}$, Paulo Roberto Leitão de Vasconcelos ${ }^{\text {IV }}$

${ }^{1}$ Research performed at the Experimental Surgery Research Laboratory (LABCEX), Department of Surgery, Federal University of Ceara (UFC), Brazil.

${ }^{I} \mathrm{PhD}$, Associate Professor, Department of Surgery, Head, LABCEX. UFC, Ceara, Brazil. Surgical procedure, samples colleting and acquisition and interpretation of data, statistical analysis, writing the report.

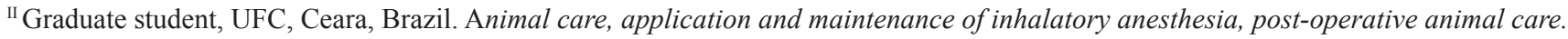

III $\mathrm{PhD}$, Associate Professor, Department of Organic and Inorganic Chemistry, UFC, Ceara, Brazil. Laboratory isolation of ternatin and interpretation of data; critical review.

Iv PhD, Associate Professor, Coordinator, Department of Surgery, Postgraduate Program, UFC, Ceara, Brazil. Designing the study and final decision to submit the manuscript for publication
\end{abstract}

\begin{abstract}
Purpose: To investigate the possible protective role of the bioflavonoid ternatin (TTN) when administered before induction of ischemia/ reperfusion injury in rat testis. Methods: Thirty-six Wistar rats were randomly assigned to 3 groups ( $\mathrm{n}=12$ ), divided in 2 subgroups $(\mathrm{n}=6)$. Saline 2.0ml (G-1), dimethylsulfoxide (DMSO) 3\% solution (G-2) or TTN $12 \mathrm{mg} / \mathrm{kg} / \mathrm{dose}$ (G-3) was administered ip. to all rats, respectively, 21, 12 and 1 hour before torsion. Anesthetized rats were subjected to ischemia ( 3 hours) induced by $720^{\circ}$ torsion of the spermatic cord. Right testis and arterial blood samples were collected at the end of ischemia (T-0), and 3 hours later (T-3) for assessment of testis malonaldehyde (MDA), reduced glutathione (GSH), and plasma total antioxidant power (TAP). Results: MDA decreased significantly $(\mathrm{p}<0,001)$ in G-2 and G-3 in T-0 and T-3 timepoints. Additional decrease in MDA was seen in G-3 after 3 hours of reperfusion (T-3). GSH increased significantly in G-2 $(\mathrm{p}<0.001)$ and G-3 $(\mathrm{p}<0.05)$ at the end the ischemia $(\mathrm{T}-0)$. A significant increase in GSH was seen 3 hours after testis detorsion (T-3) in G-2 rats. TAP values remained unchanged. Conclusion: The data provides in vivo evidence of the antiperoxidative and antioxidative properties of TTN in torted rat testis.
\end{abstract}

Key words: Flavonoids. Spermatic Cord Torsion. Ischemia. Reperfusion. Rats.

\section{RESUMO}

Objetivo: Investigar o possível efeito protetor do bioflavonóide ternatina (TTN) quando administrado antes da indução da lesão de isquemia/reperfusão testicular em ratos. Métodos: Trinta e seis ratos Wistar, aleatoriamente distribuídos em três grupos (n=12) divididos em dois subgrupos $(\mathrm{n}=6$ ) cada foram tratados com solução salina (G-1), dimetilsulfóxido (DMSO) 3\% (G-2) ou TTN 12 mg/kg/dose (G-3), administrados i.p. 21, 12 e 1 hora antes da torção. Ratos anestesiados foram submetidos à isquemia (3 horas) induzida por torção $\left(720^{\circ}\right)$ do cordão espermático direito. Amostras (testículo ipsilateral e 3,0 ml de sangue arterial) foram coletadas ao final da isquemia (T-0), e 3 horas depois (T-3) para a avaliação das concentrações de malonaldeído (MDA), glutationa reduzida (GSH) no testículo e capacidade antioxidante total (TAP) no plasma. Resultados: MDA diminuiu significativamente nos grupos G-2 e G-3 nos tempos T-0 e T-3. Houve diminuição adicional no G-3 após 3 horas. GSH aumentou significativamente nos grupos G-2 (p<0,001) e G-3 (p<0,05) no T-0 e T-3 no G-2. TAP permaneceu inalterada. Conclusão: Os achados fornecem evidências in vivo das propriedades antioxidantes e antiperoxidativas da TTN na T/D do testículo do rato.

Descritores: Flavonóides. Torção do Cordão Espermático. Isquemia. Reperfusão. Ratos. 


\section{Introduction}

Flavonoids are claimed to have protective effects against free radicals induced lipid peroxidation of living cell membranes ${ }^{1,2}$. Their protective effects may be due to their ability to scavenge reactive oxygen species ${ }^{3}$, free hydroxyl and peroxyl radicals ${ }^{4}$, or to chelate iron ions ${ }^{5}$, which are involved in the initiation of free radical reactions. Ternatin (TTN), a tetramoxyflavone from Egletes viscosa L., is known to have protective effects against hepatic oxidative damage induced by aflatoxin B1, a metabolite of Aspergillus flavus and a potent hepatotoxic ${ }^{6}$.

Testicular torsion is a common urologic emergency among newborns, children and adolescents. Events occurring during testicular torsion/detorsion (T/D) are representative of an ischemia/reperfusion (I/R) type of injury observed in other organs $^{7}$. Experimental unilateral spermatic cord torsion has shown to induce testicular biochemical changes indicative of lipid peroxidation $^{8-11}$.

To our knowledge, no study has investigated the role of TTN in testicular I/R. In the present study, we evaluated the effect of TTN on testicular oxidative stress in a rat I/R injury model.

\section{Methods}

Approval for experimental use of laboratory animals was obtained from the Committee of Ethics in Animal Research of the Federal University of Ceara (Protocol 14/02). Study groups consisted of 36 young Wistar male rats (Rattus norvegicus albinus, Rodentia, Mammalia), aged 55-65 days, weighing 175 $\pm 14 \mathrm{~g}$, provided by the Faculty of Medicine Small Animals Breeding Facility (Federal University of Ceara). Rats were housed in polypropylene cages at ambient temperature of $24^{\circ}$ on a $12 \mathrm{~h}$ lightdark cycle and allowed free access to food (Purina chow) and water until $12 \mathrm{~h}$ before the experiments.

Animals were randomly assigned to 3 groups $(n=12)$ : G-1 (Saline-control) G-2 (Vehicle) and G-3 (TTN). Rats of each group were distributed in 2 subgroups, each comprising 6 animals. Anesthetized (ether) rats were subjected to testis ischemia ( 3 hours) induced by $720^{\circ}$ torsion of the spermatic cord. After each surgical intervention the incisions were closed and the rats were returned to their cages and allowed free access to water. At the end of the experiment all animals were killed by an overdose of anesthetics. Tissue samples were snap-frozen in liquid nitrogen and stored in glass tubes at $-70^{\circ}$ until subsequent preparation and analysis of testis homogenate. Plasma samples obtained from blood after 10 minutes of refrigerated centrifugation (4000 rotations/min) and were likewise stored.

\section{Study groups}

Group 1 (saline): saline $2.0 \mathrm{ml}$ i.p., 21, 9 and 1 hour before ischemia.

Group 2 (vehicle): dimethylsulfoxide (DMSO) 3\% in $0.9 \%$ saline, $10 \mathrm{ml} / \mathrm{kg} /$ dose completing the volume for $2.0 \mathrm{ml}$ with saline, i.p., 21, 9 and 1 hour before ischemia.

Group 3 (TTN): TTN (1.2 mg/ml) i.p., suspended in DMSO $3 \%$ aqueous solution, $10 \mathrm{ml} / \mathrm{kg} /$ dose completing the volume for $2.0 \mathrm{ml}$ with saline, 21, 9 and 1 hour before ischemia.

\section{Planta material}

Egletes viscosa flower heads were collected during the dry season in northeast Brazil. Botanical identification was confirmed by Prof. A. G. Fernandes, of the Federal University of Ceará (UFC). The voucher specimen (\#16327) is deposited in the Herbarium Prisco Viana (UFC). Ternatin was isolated from dried flower buds of E. viscosa L. as per procedures and methods described previously ${ }^{12}$.

\section{Chemicals}

DMSO (purity grade: 99.9\%) was purchased from Cromato Produtos Químicos Ltda. Total Antioxidant Power kit (TA-01) was purchased from Oxford Biomedical Research. All other chemicals were purchased from standard commercial sources and were of the highest quality available.

\section{Statistical methods}

Graphpad Prism 5.0 (www.graphpad.com) was used for statistical analysis and graphics design. All data were tested for distribution. All results were expressed as mean \pm SD. Multiple comparisons were made using one-way ANOVA followed by Tukey's post-test. Values of $\mathrm{p}<.05$ were accepted as statistically significant.

\section{Results}

No animal died during the experiment. Thiobarbituric acid reactive substances (TBARS) and reduced glutathione (GSH) were assayed in testis homogenates. Total antioxidant power (TAP) was assayed in the blood plasma. 


\section{Lipid peroxidation}

MDA concentrations decreased significantly $(\mathrm{p}<0,001)$ in vehicle and TTN groups in both timepoints. Additional decrease in MDA concentrations was seen in TTN rats compared with vehicle rats after three hours (T-3). (Figure 1)

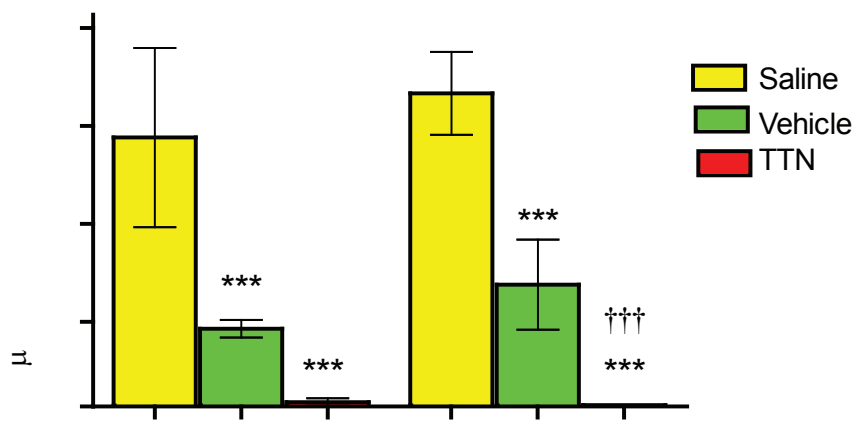

Timepoints

FIGURE1 - Thiobarbituric acid-reactive substances concentrations (micromoles of malondialdehyde per gram of fresh tissue) in the testis of saline, DMSO and ternatin (TTN) pretreated rats. Bars represent mean \pm SD of control (yellow bars), vehicle (green bars) and TTN (red bars) groups at the end of the ischemia (T-0) and during reperfusion (T-3). $* * * P<0.001$, vehicle and TTN groups are significantly different from control group by ANOVA test. $\dagger \dagger \uparrow P<0.001$, compared with vehicle group.

T-0: before detorsion; T-3, $3 \mathrm{~h}$ after detorsion.

\section{Oxidative stress}

GSH concentrations increased significantly in vehicle $(\mathrm{p}<0.001)$ and TTN $(\mathrm{p}<0.05)$ at the end the ischemia $(\mathrm{T}-0)$. A significant increase in GSH concentrations was seen 3 hours after testis detorsion (T-3) in vehicle rats. GSH concentrations in saline and TTN treated rats were not different in T-3 timepoint (Figure 2).

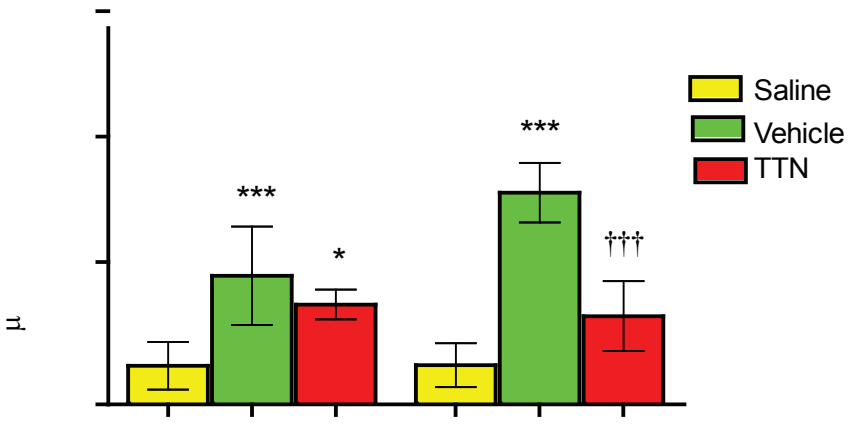

Timepoints

FIGURE 2 - Reduced glutathione (GSH) concentrations (micromoles of GSH per gram of fresh tissue) in testis homogenates of saline, DMSO and ternatin (TTN) pretreated rats. Bars represent mean \pm SD of control (yellow bars), vehicle (green bars) and TTN (red bars) groups at the end of the ischemia (T-0) and during reperfusion (T-3), Vehicle $(* * * P<0.001)$ and ternatin groups $(\mathrm{P}<0.05)$ are significantly different from control group by ANOVA test. $\uparrow \uparrow \uparrow P<0.001$ compared with vehicle group. $\mathrm{T}-0$ : before detorsion; $\mathrm{T}-3,3 \mathrm{~h}$ after detorsion

\section{Plasma total antioxidant power}

Concentrations of TAP remained unchanged in vehicle and TTN groups. Antioxidants (Figure 3).

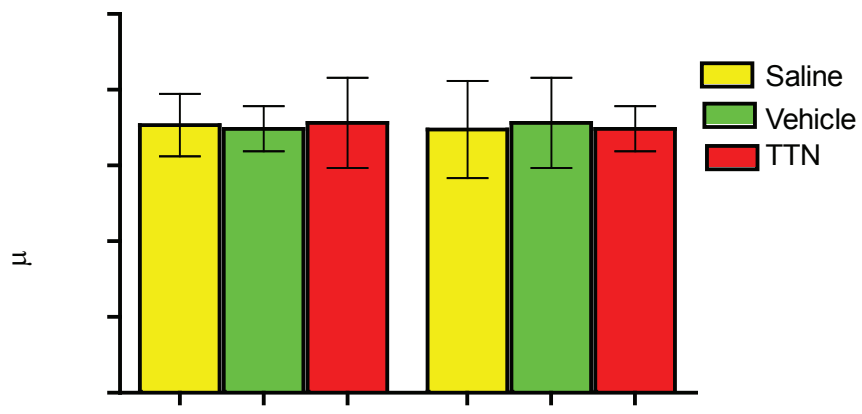

Timepoints

FIGURE 3 - Plasma concentrations of total antioxidants (micromoles) in saline, DMSO and ternatin (TTN) pretreated rats. Bars represent mean \pm SD of control (yellow bars), vehicle (green bars) and TTN (red bars) groups at the end of the ischemia (T-0) and during reperfusion (T-3). Values were not different in T- 0 and T-3 timepoints.

$\mathrm{T}-0$ : before detorsion; $\mathrm{T}-3,3 \mathrm{~h}$ after detorsion

\section{Discussion}

There is increasing evidence to suggest that toxic oxygen radicals play a role in the pathogenesis of ischemia/reperfusion injury in the testis. These free radicals react with lipid in cells and mitochondrial membranes forming lipid peroxides. Peroxidation of the lipid in membrane changes membrane permeability or disrupts 
membrane and cell integrity. Lipid peroxidation is probably the most extensively investigated process induced by free radicals ${ }^{13}$.

Different therapeutic strategies have been investigated with the aim of reducing testis ischemia/reperfusion damage. Akgür et al. ${ }^{8}$ submitted adult rats to ischemia from 1-5 hours followed by reperfusion (1-5 hours). Rats pretreated with allopurinol (200 $\mathrm{mg} / \mathrm{kg}$ ) did not show increase in lipid peroxidation. Turan et al. ${ }^{14}$ studied the effects of vitamin E administered to adult SpragueDawley rats submitted to the torsion/destorsion of the testicle. Assessment of MDA showed that the vitamin E administered before or after testicular detorsion was innocuous ${ }^{14}$.

The lipid peroxidation inhibitory effects of several flavonoids such as luteolin, apigenin, galangin, gardenin D, $(+)$ catechin $^{15}$, quercitin ${ }^{16}$ and rutin (quercetin-3-rhamnosyl glucoside $)^{17}$ have been previously reported. Pretreatment with ternatin enhanced higher antiperoxidative capacity of testis. This finding is verified by the significant decrease $(\mathrm{P}>.0001)$ in MDA concentrations in ternatin pretreated animals when compared with DMSO and saline pretreated rats. The increase of GSH concentrations in TTN pretreated suggests that this flavonoid may attenuate the oxidative stress induced by $I / R$ in rat testis immediately after detorsion. This protection is of short duration as this effect is not present after 3 hours. The use of TTN did not change plasma total antioxidants concentrations. This suggests TTN exerts no systemic antioxidant effects in rats submitted to $\mathrm{T} / \mathrm{D}$ of the spermatic cord.

The data provides in vivo evidence of the antiperoxidative and antioxidative properties of TTN in torted testis. This effect was increased by the antioxidative effect of the vehicle. DMSO protective effects in torted testis has been demonstrated in one of our recently published paper dealing with this subject ${ }^{18}$.

\section{Conclusion}

The results of the present study support the view that ternatin can exert a protective effect against testis tissue lipid peroxidation injury and oxidative stress caused by ischemia/ reperfusion in rats subjected to T/D of the spermatic cord.

\section{References}

1. Cholbi MR, Paya M, Alcaraz MJ.Inhibitory effects of phenolic compounds on CCl4-induced microsomal lipid peroxidation. Experientia. 1991;47(2):195-9.

2. Seth P, Kumari R, Madhavan S, Singh AK, Mani H, Banaudha KK, Sharma SC, Kulshreshtha DK, Maheshwari RK. Prevention of renal ischemia-reperfusion-ind prevention of renal ischemiareperfusion-induced injury in rats by picroliv. Biochem Pharmacol.
2000;59(10):1315-22.

3. Sorata Y, Takahama U, Kimura M. Protective effect of quercetin and rutin on photosensitized lysis of human erythrocytes in the presence of hematoporphyrin. Biochim Biophys Acta. 1984;799:313-7.

4. Maridonneau-Parini I, Braquet P, Garay RP. Heterogeneous effect of flavonoids on $\mathrm{K}+$ loss and lipid peroxidation induced by oxygen-free radicals in human red cells. Pharmacol Res Commun. 1986;18(1):61-72.

5. Morel I, Abaléa V, Sergent O, Cillard P, Cillard J. Involvement of phenoxyl radical intermediates in lipid antioxidant action of myricetin in iron-treated rat hepatocyte culture. Biochem Pharmacol. 1998;55(9):1399-404.

6. Souza MF, Tomé AR, Rao VS. Inhibition by the bioflavonoid ternatin of aflatoxin B1-induced lipid peroxidation in rat liver. J Pharm Pharmacol. 1999;51(2):125-9.

7. Can C, Tore F, Tuncel N, Uysal O, Gurer F, Tuncel M: Protectıve effect of vasoactive intestinal peptide on testicular torsion-detorsion injury: association with heparin-containing mast cells. Urology. 2004;63:195-200.

8. Akgür FM, Kilinç K, Aktug T, Olguner M. The effect of allopurinol pretreatment before detorting testicular torsion. J Urol.1994;151(6):1715-7.

9. Ozkan KU, Boran C, Kilinc M, Garipardic M, Kurutas EB. The effect of zinc aspartate pretreatment on ischemia-reperfusion injury and early changes of blood and tissue antioxidant enzyme activities after unilateral testicular torsion-detorsion. J Pediatr Surg. 2004;39(1):91-5.

10. Guimarães SB, Aragão AA, Santos JM, Kimura Ode S, Barbosa $\mathrm{PH}$, Vasconcelos PR. Oxidative stress induced by torsion of the spermatic cord in young rats. Acta Cir Bras. 2007;22(1):30-3.

11. Guimarães SB, Santos JM, Aragão AA, de Sandes Kimura O, Barbosa $\mathrm{PH}$, de Vasconcelos PR. Protective effect of alpha-lipoic acid in experimental spermatic cord torsion. Nutrition. 2007;23(1):76-80.

12. Lima MA, Silveira ER, Marques MS, Santos RH, Gambardela MT. Biologically active flavonoids and terpenoids from Egletes viscosa. Phytochemistry. 1996;41(1): 217-23.

13. Yu BP. Cellular defenses against damage from reactive oxygen species. Physiol Rev. 1994;74(1):139-62.

14. Turan C, Küçükaydin N, Bekerecioğlu A, Kazez A, Doğan $\mathrm{P}$, Küçükaydin $\mathrm{M}$. The effect of vitamin $\mathrm{E}$ on ipsilateral and contralateral testis following unilateral testicular torsion in rats. Res Exp Med (Berl). 1996;196(4):243-6.

15. Cholbi MR, Paya M, Alcaraz MJ. Inhibitory effects of phenolic compounds on CCl4-induced microsomal lipid peroxidation. Experientia 1991;47(2):195-9.

16. Kanter M. Protective effect of quercetin on liver damage induced by biliary obstruction in rats. J Mol Histol. 2010;41(6):395-402.

17. Korkmaz A, Kolankaya D. Protective effect of rutin on the ischemia/ reperfusion induced damage in rat kidney. J Surg Res. 2010;164(2):309-15.

18. Guimarães SB, Kimura OS, Vasconcelos PR. Dimethylsulfoxide attenuates ischemia-reperfusion injury in rat testis. Acta Cir Bras. 2010;25(4):357-61.

\section{Correspondence:}

Conflict of interest: none Correspondence: Sérgio Botelho Guimarães Rua Barão de Aratanha, 1465 60050-071 Fortaleza-CE Brasil

Tel: (55 85)3226-2400 sergiobotelho@terra.com.br
Financial source: none

Received: November 15, 2010 Review: January 17, 2011 Accepted: February 18, 2011 